\title{
Toxic effects of the dinoflagellate Heterocapsa circularisquama on clearance rate of the blue mussel Mytilus galloprovincialis
}

\author{
Yukihiko Matsuyama $^{1, *}$, Takuji Uchida ${ }^{1}$, Tsuneo Honjo ${ }^{2}$ \\ ${ }^{1}$ Nansei National Fisheries Research Institute, Maruishi, Ohno, Saeki, Hiroshima 739-04, Japan \\ ${ }^{2}$ Faculty of Agriculture, Kyushu University, Hakozaki, Higashi, Fukuoka 812-81, Japan
}

\begin{abstract}
The effects of Heterocapsa circularisquama (Peridiniales, Dinophyceae) on the clearance rate of blue mussel Mytilus galloprovincialis were studied in the laboratory to clarify the mechanism involved in the toxic effects of dinoflagellates on bivalve mollusks. The clearance rate of blue mussels was significantly reduced when exposed to $H$. circularisquama, even at a low dinoflagellate cell density (50 cells $\mathrm{ml}^{-1}$ ). Mussels also showed extreme retraction of the mantle edge and no production of feces or pseudofeces. The reduction in clearance rate did not seem to be caused by size, density, or shape of $H$. circularisquama, since no inhibitory effect was observed when mussels were exposed to other morphologically similar dinoflagellates, i.e. Scrippsiella trochoidea and Heterocapsa triquetra. A filtrate of the $H$. circularisquama culture did not repress the clearance rate of $M$. galloprovincialls. 'Naked cells' of $H$. circularisquama (without cell wall), which were prepared by centrifugation, showed no inhibitory effect on clearance rate. Therefore, it is quite likely that the source of toxicity of $H$. circularisquama is localized on the cell surface. The inhibitory effect of $H$. circularisquama was inactivated by treatment of intact cells with trypsin and sodium dodecylsulfate. These results indicate that the toxic response of $M$. galloprovincialis to $H$. circularisquama is caused by a protein-like substance involving the outer cell components. This is the first study to explain the specific inhibition process of $H$. circularisquama on the filtering activities of bivalve mollusks.
\end{abstract}

KEY WORDS: Heterocapsa circularisquama Mytilus galloprovincialis - Clearance rate - Bivalve Dinoflagellate Toxic effect

\section{INTRODUCTION}

Harmful phytoplankton blooms occur worldwide, causing serious social problems and seriously affecting shellfish and aquaculture industries (Shumway 1990, Hallegraeff 1993, Anderson 1994, Honjo 1994). The paralytic shellfish poisoning (PSP) of shellfish by members of the genus Alexandrium has been well documented. These toxic microalgae not only bring about PSP in humans who have consumed contaminated bivalves, but also affect the physiological status of the filter-feeding bivalves themselves (Gainey \& Shumway

•E-mail: yukihiko@nnf.affrc.go.jp
1988, Lesser \& Shumway 1993). Gyrodinium aureolum, which is associated with massive shellfish mortality (Mahoney et al. 1990, Heinig \& Campbell 1992), causes reduction of clearance (Widdows et al. 1979) and shell growth rates (Nielsen \& Stromgren 1991) and cellular damage in the gut (Widdows et al. 1979) of the blue mussel Mytilus edulis. Moreover, abnormal responses of both juvenile and adult bivalves exposed to Aureococcus anophagefferense (Gainey \& Shumway 1991) and Prorocentrum minimum (Wikfors \& Smolowitz 1995) have been reported. Thus, harmful effects of certain phytoflagellates to marine bivalve mollusks are extensive.

Heterocapsa circularisquama (Peridiniales, Dinophyceae) is a 'novel' red tide species which has caused 
mass mortalities of bivalves in embayments of western Japan since 1988 (Yamamoto \& Tanaka 1990, Horiguchi 1995, Matsuyama et al. 1995, Matsuyama et al. 1996). Incidences of red tide caused by this alga have increased recently, and the economic loss to aquaculture in terms of death of bivalves has caused industrial and social concern (Matsuyama et al. 1996). The red tide of $H$. circularisquama kills more than 12 bivalve species, but no harmful effects on wild fish populations, cultured fish, or on public health in general have been reported.

Recently, the lethal effects of Heterocapsa circularisquama on pearl oyster Pinctada fucata were demonstrated under laboratory conditions (Nagai et al. 1996). Juvenile pearl oysters exposed to 5000 to $10000 \mathrm{H}$. circularisquama cells $\mathrm{ml}^{-1}$ showed vigorous clapping and shrinkage of their mantle edges and gills. Approximately $50 \%$ of the pearl oysters subsequently underwent cardiac arrest and died after $48 \mathrm{~h}$ (Nagai el al. 1996). These toxic effects on the survival and feeding behavior of pearl oysters implicate direct cytotoxicity, but details of the processes by which bivalves are affected by this alga are still unclear.

In this study, we determined the clearance rate of blue mussel Mytilus galloprovincialis exposed to physically and chemically treated cells of Heterocapsa circularisquama in order to verify the toxicity of this alga on bivalves. On the basis of the results obtained, we show that the toxicity to the bivalves involves outer components of $H$. circularisquama cells.

\section{MATERIALS AND METHODS}

Mussel preparation. Adult Mytilus galloprovincialis [shell height $25.7 \pm 1.4$ (SD) $\mathrm{mm}$ ], which were collected from Hiroshima Bay in the Seto Inland Sea, Japan, in March 1994, were used as the assay animals in the present study. The collected mussels were maintained in running seawater at temperatures ranging from 15 to $18^{\circ} \mathrm{C}$ and fed cultured phytoplankters (Isochrysis galbana, Skeletonema costatum) over a $10 \mathrm{~d}$ period. Prior to the experiments, each individual was placed into a container containing filtered seawater (GF/F Whatman, pore size ca $0.7 \mu \mathrm{m}$ ) at $20 \pm 1.5^{\circ} \mathrm{C}$, and gut contents were allowed to clear over $24 \mathrm{~h}$. Seawater was replenished at least once prior to the start of the experiments. Healthy individuals, displaying byssus thread production and full extension of their mantle edge, were used for the experiments.

Algal culture. Heterocapsa circularisquama used in the present study were isolated from the surface water of Ago Bay, Mie Prefecture in 1992. Scrippsiella trochoidea and Heterocapsa triquetra were isolated from the surface water of Hiroshima Bay in 1993. Clonal cul- tures of these species were obtained by repeated washings using capillary pipettes. The clonal culture of I. galbana was provided by Dr H. Iwasaki (Mie University) The algae were cultured in modified SWM-3 medium (Chen et al. 1969, Itoh \& Imai 1987) at $22^{\circ} \mathrm{C}$ on a $12 \mathrm{~h}$ light:12 h dark cycle under illumination at $100 \mu \mathrm{E} \mathrm{m}^{-2} \mathrm{~s}^{-1}$ provided by cool-white fluorescent lamps. All cultures were non-axenic. Cultures in the late exponential to early stationary phase (10 to $16 \mathrm{~d}$ after inoculation) were used for the experiments. Measurements of algal cell size were conducted for immobilized cells ( $n=30$ ) treated with nickel chloride (final concentration ca $0.4 \mu \mathrm{g} \mathrm{ml}^{-1}$ ) under the microscope.

Measurement of clearance rate. Clearance rate (see Omori \& Ikeda 1984) was measured by an indirect method which determines the time course decrease of microalgal cell density resulting from mussel filtration. For simple and rapid measurements, microalgal cell densities were determined with a fluorometer (Turner Designs Co., CA, USA, model 110), based on the measurements of in vivo chlorophyll fluorescence in the cuvettes (Brand \& Guillard 1980). Ambient water samples $(5 \mathrm{ml})$ were transferred to a cuvette with an automatic pipette and fluorescence values of the culture were directly measured. There was no fluorescence detected in the filtered seawater (background) throughout the experiments. Clearance rates of the mussels were calculated using the following equation (Coughian 1969):

$$
C R=\ln \left(F_{0} / F_{t}\right) \cdot M / t
$$

where $C R$ is clearance rate, $F_{0}$ is the initial fluorescence value of ambient water, $F_{t}$ is fluorescence after time $t, M$ is the total volume of ambient water, and $t$ is the time after the start of the experiments $(10$ to $20 \mathrm{~min}$ ).

Mussels were placed in aerated semi-transparent plastic beakers containing 50 to $100 \mathrm{ml}$ of microalgal culture diluted with filtered seawater. Stirring and aeration were not performed in order to avoid any disturbance of the filtering processes of the blue mussel. When feces and pseudofeces of a mussel were observed during the experiment, they were removed with Pasteur pipettes immediately. All experiments were carried out in triplicate. Data are expressed as means $\pm \mathrm{SD}$, and statistical analyses were performed with Student's $t$-test

When the experiments involved low cell densities ( $\leq 500$ cells $\mathrm{ml}^{-1}$ ) of Heterocapsa circularisquama, cells of another algal species, Isochrysis galbana (50000 cells $\mathrm{ml}^{-1}$ ), were given in combination for the measurement of clearance rate. Clearance rate of mussels exposed to $80000 \mathrm{I}$. galbana cells $\mathrm{ml}^{-1}$ was defined as the control in the present study. I. galbana is generally known to be non-toxic. 
Cell treatments of Heterocapsa circularisquama. In order to examine the effects of an extracellular metabolite of $H$ circularisquama on Mytilus galloprovincialis, filtrate was prepared from a culture of $H$. circularisquama (100 000 cells $\mathrm{ml}^{-1}$ ) by gentle filtration $(<20 \mathrm{~mm} \mathrm{Hg})$, using a glass-fiber filter (GF/F). Physically treated cells of $H$. circularisquama were prepared by centrifugation and sonication. The cultures $\left(50000\right.$ cells ml $\left.{ }^{-1}\right)$ were centrifuged at $2000 \mathrm{rpm}(720 \times$ g) for $5 \mathrm{~min}$. After decantation, pellets were resuspended in filtered seawater at a concentration of 8000 cells $\mathrm{ml}^{-1}$. Sonication was applied for about $60 \mathrm{~s}$ to $H$. circularisquama cultures containing 8000 cells ml- ${ }^{-1}$.

Heterocapsa circularisquama were chemically treated at $25^{\circ} \mathrm{C}$ for $2 \mathrm{~h}$ using $5 \mathrm{ml}$ of culture containing 20000 to 50000 cells ml ${ }^{-1}$. Chemicals [EDTA, trypsin, sodium dodecylsulfate (SDS), Triton X-100, and sodium deoxycholate] were obtained from Wako Pure Chemical Ind. Ltd (Osaka, Japan). Concentrations of each chemical employed in the present study are as follows: EDTA, $24 \mathrm{\mu g} \mathrm{ml}^{-1}$; trypsin, $350 \mu \mathrm{g} \mathrm{ml}^{-1}$; SDS, 10 to $50 \mu \mathrm{g}$ $\mathrm{ml}^{-1}$; Triton X-100, $7.4 \mu \mathrm{g} \mathrm{ml}^{-1}$; and sodium deoxycholate, $23 \mu \mathrm{g} \mathrm{ml}^{-1}$. Each chemical was used at a concentration lower than that which would inhibit the swimming ability of $H$. circularisquama. The final density of these treated cells was adjusted to 250 to 290 cells $\mathrm{ml}^{-1}$ in filtered seawater prior to the experiments. Chemicals which were carried over into the bioassay procedure had no effect on mussel clearance rate.

\section{RESULTS}

\section{Measurement of clearance rate}

Relationships between cell density and fluorescence value of each microalgal species are given in Fig. 1. Linear relationships were clearly demonstrated over a wide range of cell densities and the correlation coefficients ranged from 0.9892 to 0.9941 . The fluorometric technique, used in this study to determine chl a of the microalgae, allowed for rapid and simple measurements of the clearance rates of Mytilus galloprovincialis with high levels of reproducibility.

\section{Effects of intact cells}

The mean cell length of algae used was $32.8 \pm 3.0$ (SD) $\mu \mathrm{m}$ in Scrippsiella trochoided, $25.5 \pm 2.2 \mu \mathrm{m}$ in Heterocapsa triquetra, $21.8 \pm 2.5 \mu \mathrm{m}$ in $H$. circularisquama, and $4.4 \pm 0.8 \mu \mathrm{m}$ in Isochrysis galbana.

Table 1 shows the clearance rates ( $\mathrm{ml}$ mussel ${ }^{-1} \mathrm{~h}^{-1}$ ) of Mytilus galloprovincialis exposed to each of the 4 phytoflagellate species. Initial cell density was
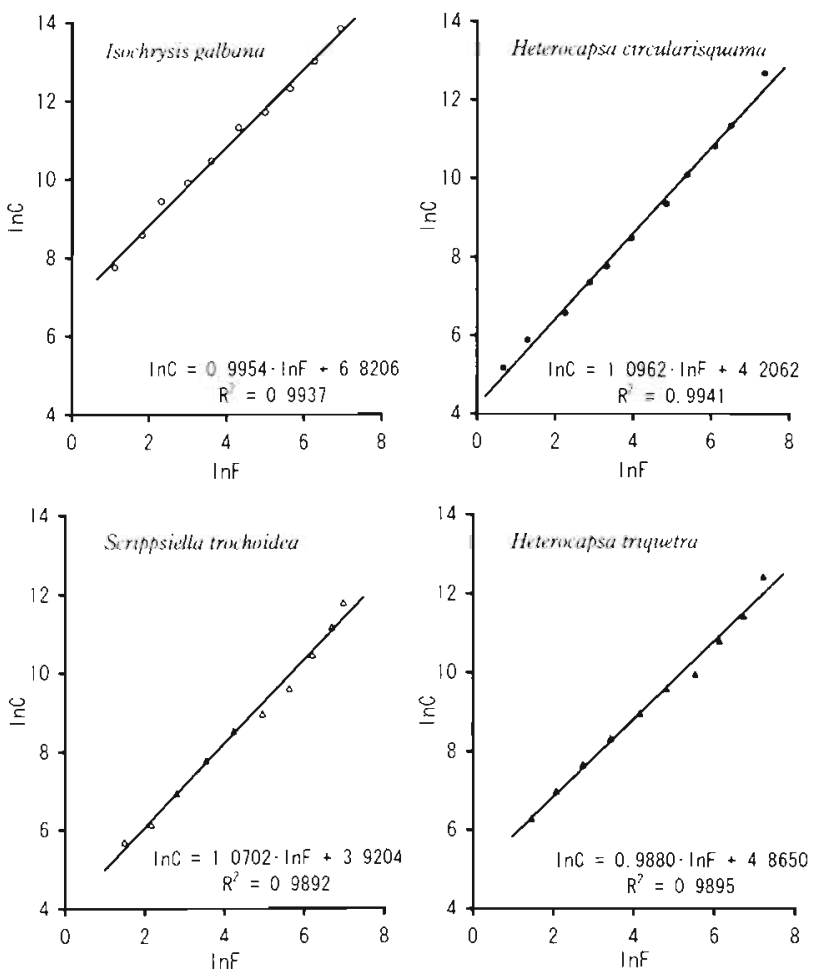

Fig. 1 Correlations between natural logarithm of cell densities $\left(C_{i}\right.$ cells $\left.\mathrm{ml}^{-1}\right)$ and natural logatithm of in vivo fluorescence ( $F$; relative units) for the 4 microalgal species used in this study

Table 1. Clearance rates ( $\mathrm{ml}$ mussel ${ }^{-1} \mathrm{~h}^{-1}$; mean $\pm \mathrm{SD}$ ) of Mytilus galloprovincialis exposed to 4 different species of microalgae. Cell densities are 80000 cells $\mathrm{ml}^{-1}$ for Isochrysis galbana (control) and 8000 cells $\mathrm{ml}^{-1}$ for the other species. ns: not significant

\begin{tabular}{|lccc|}
\hline Microalgal & $\begin{array}{c}\text { Clearance } \\
\text { rate }\end{array}$ & $\begin{array}{c}\% \\
\text { control }\end{array}$ & t-test \\
\hline Jsochrysis galbana (control) & $1015 \pm 135$ & - & - \\
Scrippsiella trochoidea & $1010 \pm 95$ & 99 & $\mathrm{~ns}$ \\
Heterocapsa triquetra & $1008 \pm 112$ & 99 & $\mathrm{~ns}$ \\
Heterocapsa circularisquama & $10 \pm 1$ & 0.97 & $\mathrm{p}<0.001$ \\
\hline
\end{tabular}

8000 cells $\mathrm{ml}^{-1}$ for Scrippsiella trochoidea, Heterocapsa triquetra and $H$. circularisquama, and 80000 cells $\mathrm{ml}^{-1}$ for Isochrysis galbana. Clearance rates for $S$. trochoidea and $H$. triquetra were almost the same as that for I. galbana, which is generally known as non-toxic and is used as feed for bivalves. In contrast, a remarkable reduction in clearance rate was observed in the case of $H$. circularisquama. Although the mussels exposed to $H$. circularisquama cells did not close their shells completely (during the 10 to 20 min experimental trials), their inhalant opening and exhalant siphon 


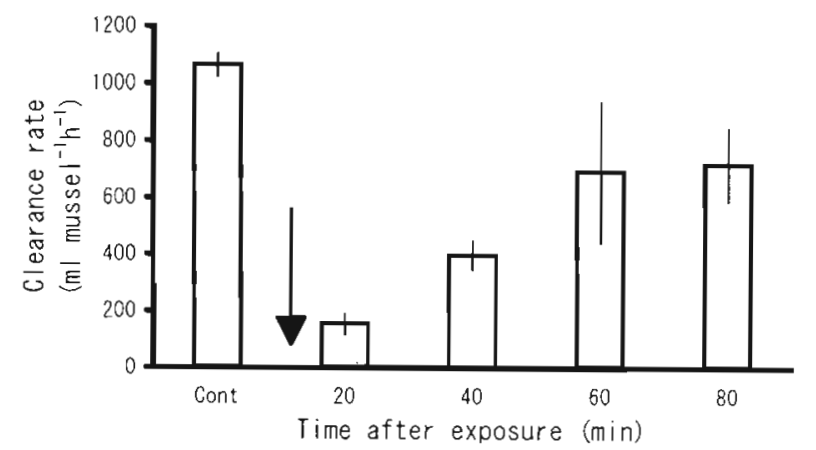

Fig. 2. Change in clearance rate of Mytilus galloprovincialis pre-exposed to 5000 intact Heterocapsa circularisquama cells $\mathrm{ml}^{-1}$ for about $30 \mathrm{~min}$. (Control: Isochrysis galbana, 80000 cells $\mathrm{ml}^{-1}$ ). Arrow denotes the replenishment of the media to 80000 cells $\mathrm{ml}^{-1}$ of Isochrysis galbana. Error bars show $\pm \mathrm{SD}$

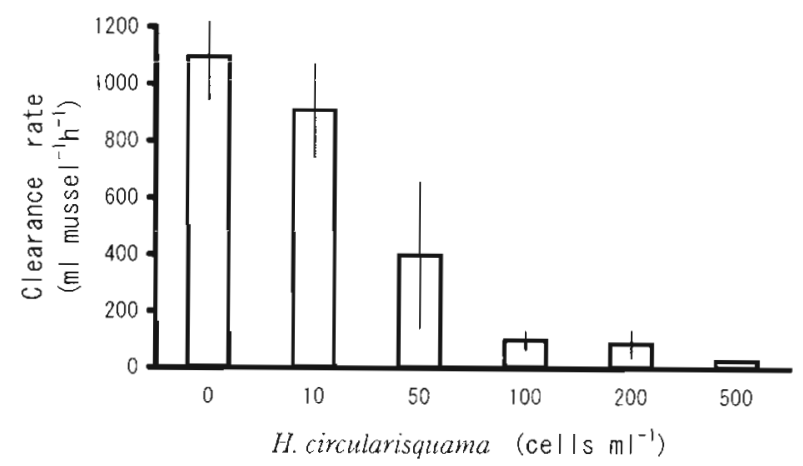

Fig. 3. Changes in clearance rate of Mytilus galloprovincialis exposed to various concentrations of Heterocapsa circularisquama. Error bars show $\pm \mathrm{SD}$

were obstructed due to extreme retraction of the mantle. The mussels which were exposed to $5000 \mathrm{H}$. circularisquama cells $\mathrm{ml}^{-1}$ (30 min) still exhibited refusal behavior up to $80 \mathrm{~min}$ after the ambient water was replenished with a medium containing $I$. galbana cells (Fig. 2).

Fig. 3. shows the relationships between cell density of Heterocapsa circularisquama and clearance rate of Mytilus galloprovincialis. Each measurement was conducted using bi-algal conditions, i.e. various concentrations of $H$. circularisquama combined with $50000 I$. galbana cells $\mathrm{ml}^{-1}$. Marked decline of the mean clearance rate was observed above a density of $50 \mathrm{H}$. circularisquama cells $\mathrm{ml}^{-1}$. The mean clearance rate at 500 cells $\mathrm{ml}^{-1}$ was reduced to $2.6 \%$ of the control clearance rate. No significant $(p>0.2)$ differences were found between the mean clearance rate of the mussels exposed to $10 \mathrm{H}$. circularisquama cells $\mathrm{ml}^{-1}$ and the mean clearance rate of the controls. The mean clearance rates measured during the exposure of blue mussels to 50 and $100 \mathrm{H}$. circularisquama cells $\mathrm{ml}^{-1}$ were significantly lower $(p<0.05$ and $p<0.001)$ than clear- ance rates in the controls. Thus, reduction of the clearance rate of $M$. galloprovincialis strongly depends on the cell density of $H$. circularisquama.

\section{Effects of physical treatments}

Table 2 shows the clearance rates of Mytilus galloprovincialis exposed to various physically treated cells of Heterocapsa circularisquama. The clearance rates of mussels exposed to filtrate prepared from $H$. circularisquama culture $\left(100000\right.$ cells $\left.\mathrm{ml}^{-1}\right)$ was $892 \mathrm{ml}$ mus$\mathrm{sel}^{-1} \mathrm{~h}^{-1}$ (Table 2). No significant $(\mathrm{p}>0.2)$ inhibition of clearance rates or refusal behaviors, such as retraction of mantle, valve closure and pseudofeces production, were observed in mussels exposed to filtrate of $H$. circularisquama.

Most of the sonicated cells of Heterocapsa circularisquama retained their shape, but sonication caused cell wall shearing and loss of motility (about 90\%). Cells undergoing centrifugation completely retained their shapes but lost their outer components. Clearance rates were calculated to be $590 \mathrm{ml}$ mussel ${ }^{-1} \mathrm{~h}^{-1}$ and $1026 \mathrm{ml} \mathrm{mussel}^{-1} \mathrm{~h}^{-1}$ for sonicated and centrifugated cells, respectively. No significant ( $p>0.5)$ reduction in clearance rates of mussels was observed when exposed to centrifugated cells. Mussels exposed to sonicated cells exhibited a significant $(\mathrm{p}<0.05)$ reduction in clearance rates; however, reduction of the activity was about $50 \%$ of that in the assay using similar concentrations of intact $H$. circularisquama cells (see Table 2). Therefore, $H$. circularisquama cells, stripped of their outer components by sonication and centrifugation, exhibited little effect on clearance rates of the mussel.

\section{Effects of chemical treatment}

Clearance rate of Mytilus galloprovincialis exposed to Heterocapsa circularisquama cells treated with tryp-

Table 2. Clearance rates $\left\{m l\right.$ musse $\mathrm{l}^{-1} \mathrm{~h}^{-1}$; mean \pm SD j of Mytilus galloprovincialis exposed to physically treated Heterocapsa circularisquama cells (control: Isochrysis galbana, 8000 cells $\mathrm{ml}^{-1}$. Cell density of $H$. circularisquama was 8000 cells $\mathrm{ml}^{-1}$ for each treatment. ns: not significant

\begin{tabular}{|lccc|}
\hline Treatment & Clearance rate & $\%$ control & $t$-test \\
\hline Control & $1112 \pm 266$ & - & - \\
Untreated & $3 \pm 1$ & 0.27 & $\mathrm{p}<0.005$ \\
Filtrate & $892 \pm 170$ & 80 & $\mathrm{~ns}$ \\
Sonication & $590 \pm 218$ & 53 & $\mathrm{p}<0.05$ \\
Centrifugation & $1026 \pm 231$ & 92 & $\mathrm{~ns}$ \\
& & & \\
\hline
\end{tabular}


Table 3. Clearance rates ( $\mathrm{ml}$ mussel ${ }^{-1} \mathrm{~h}^{-1}$; mean $\pm \mathrm{SD}$ ) of Mytilus galloprovincialis exposed to chemically treated Heterocapsa circularisquama cells (control: Isochrysis galbana, 8000 cells $\mathrm{ml}^{-1}$ ). Cell density of $H$. circularisquama ranged from 260 to 290 cells $\mathrm{ml}^{-1}$ ns: not significant

\begin{tabular}{|lccc|}
\hline Treatment & Clearance rate & $\%$ control & $t$-test \\
\hline Control & $1068 \pm 206$ & - & - \\
Untreated & $156 \pm 46$ & 15 & $\mathrm{p}<0.001$ \\
EDTA & $131 \pm 5$ & 12 & $\mathrm{p}<0.005$ \\
Trypsin & $911 \pm 128$ & 85 & ns \\
\hline
\end{tabular}

Table 4. Clearance rates (ml mussel ${ }^{-1} \mathrm{~h}^{-1}$; mean $\pm \mathrm{SD}$ ) of Mytilus galloprovincialis exposed to chemically treated Heterocapsa circularisquama cells (control: Isochrysis galbana, 8000 cells $\mathrm{ml}^{-1}$ ). Cell density of $H$. circularisquama ranged from 250 to $280{\text { cells } \mathrm{m}^{-1}}^{-1}$ ns: not significant

\begin{tabular}{|lccc|}
\hline Treatment & Clearance rate $\%$ control & $t$-test \\
\hline Control & $1188 \pm 203$ & - & - \\
Untreated & $230 \pm 116$ & 19 & $\mathrm{p}<0.001$ \\
SDS & $1096 \pm 69$ & 92 & $\mathrm{~ns}$ \\
Sodium deoxycholate & $207 \pm 87$ & 17 & $\mathrm{p}<0.005$ \\
Triton X-100 & $395 \pm 147$ & 33 & $\mathrm{p}<0.001$ \\
\hline
\end{tabular}

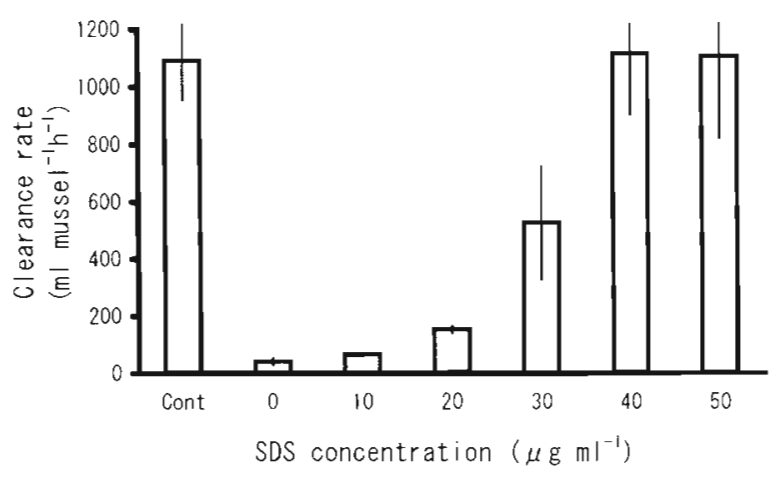

Fig. 4. Changes in clearance rate of Mytilus galloprovincialis exposed to Heterocapsa circularisquama (1000 to 1120 cells $\mathrm{ml}^{-1}$ ) pre-treated with various concentrations of SDS. Error bars show $\pm \mathrm{SD}$

sin was determined to be $911 \mathrm{ml}$ mussel ${ }^{-1} \mathrm{~h}^{-1}$, which is $85 \%$ of that in the control (Table 3 ). Significant $(p<$ 0.005 ) reduction of clearance rate was observed when the dinoflagellate was treated with EDTA. Table 4 shows clearance rates of $M$. galloprovincialis exposed to $H$. circularisquama cells treated with the surfaceactive chemicals. Clearance rates were $1096 \mathrm{ml}$ mus$\mathrm{sel}^{-1} \mathrm{~h}^{-1}$ for $\operatorname{SDS}\left(50 \mu \mathrm{g} \mathrm{ml} \mathrm{l}^{-1}\right), 395 \mathrm{ml} \mathrm{mussel}^{-1} \mathrm{~h}^{-1}$ for Triton $\mathrm{X}-100$, and $207 \mathrm{ml}$ mussel $\mathrm{l}^{-1} \mathrm{~h}^{-1}$ for sodium deoxycholate. SDS treated cells demonstrated little inhibitory effect on the clearance rate of mussels $192 \%$ of controls). In this case, no refusal behavior was observed throughout the experiments. However, the inhibitory effect of $H$. circularisquama on clearance rates was still observed when the alga was treated with other chemicals.

Fig. 4 shows the effects of SDS concentration on clearance rates of mussels exposed to SDS-treated Heterocapsa circularisquama cells. Clearance rate increased with increasing SDS concentration. The difference between control and treatment clearance rates was not significant $(p>0.5)$ when algae were treated with SDS in excess of $40 \mu \mathrm{g} \mathrm{ml} \mathrm{m}^{-1}$

\section{DISCUSSION}

\section{Toxic effects of Heterocapsa circularisquama on Mytilus galloprovincialis}

Mytilus galloprovincialis fed well on the 2 dinoflagellates Scrippsiella trochoidea and Heterocapsa triquetra as well as on Isochrysis galbana. Refusal behavior was not observed when the mussels were exposed to the cells of these species. In contrast, Heterocapsa circularisquama cells were strongly rejected by the mussels, with refusal behavior manifested by an extreme retraction of the mantle. Generally, filtration processes of bivalves are influenced by physical aspects of the particles: size, density, electric charge, and morphology (Ali 1970, Schulte 1975, Winter 1978, Jørgensen 1990). In the present study, however, size, density, and morphology of 3 dinoflagellates were not so different. Therefore, the inhibition of $M$. galloprovincialis clearance rate is probably not due to physical aspects of $H$. circularisquama.

The inhibitory effect of Heterocapsa circularisquama appears to occur even at low concentrations, that is Mytilus galloprovincialis showed a significantly reduced clearance rate at $50 \mathrm{H}$. circularisquama cells $\mathrm{ml}^{-1}$. In natural populations of Gyrodinium aureolum, which is considered toxic to shellfish, significant inhibition of the clearance rate of Mytilus edulis occurs at 500 cells $\mathrm{ml}^{-1}$, but not at 200 cells $\mathrm{ml}^{-1}$ (Widdows et al. 1979). In contrast to $H$. circularisquama, Heterocapsa triquetra (which has worldwide distribution) did not induce refusal behavior in $M$. galloprovincialis and did not affect the clearance rate of $M$. galloprovincialis in the present study.

Recent studies demonstrate that bivalves can selectively capture and ingest food particles. Captured particles are sorted by means of their size, shape, and chemical composition on the gill, ctenidia and labial palps of bivalves (Shumway et al. 1985). Rejected par- 
ticles are filtered and ejected as pseudofeces and/or ingested at low levels (Shumway et al. 1985). Heterocapsa circularisquama cells were still taken up at low levels when extreme mantle retraction was evident in Mytilus galloprovincialis. Inhibition of the clearance rate was sustained not only during experiments but also up to $80 \mathrm{~min}$ after ambient water was replaced with I. galbana culture (Fig. 2). This type of inhibition has not been previously reported.

\section{Characterization of chemical components}

Reduction in clearance rate was significant when $\geq 50$ intact Heterocapsa circularisquama cells $\mathrm{ml}^{-1}$ were used in the present experiment. However, no inhibitory effects on clearance rate were observed with the filtrate of dense $H$. circularisquama culture ( 100000 cells $\left.\mathrm{ml}^{-1}\right)$. Thereiore, it seems iikely that $H$. circularisquama cells do not produce extracellular metabolites which repress mussel clearance rates, apart from in their cell walls. A previous study (Nagai et al. 1996) also reported that death of juvenile pearl oysters was not caused by extracellular metabolites of $H$. circularisquama in the medium. Furthermore, filtrate of $H$. circularisquama has not been observed to have any toxic effect on the survival of the naked dinoflagellate Gyrodinium instriatum, whereas intact cells of $H$. circularisquama kill $G$. instriatum upon contact (Uchida et al. 1995).

'Naked cells' of Heterocapsa circularisquama prepared by centrifugation lost their inhibitory effect on mussels. Outer components (outer membrane, plates, scale, flagellum etc.) of $H$. circularisquama cells are easily removed by centrifugation and sonication. Thus, toxicity of $H$. circularisquama to blue mussels seems to be closely related to the outer components of the cells. Toxicity of $H$. circularisquama was detected neither in extracellular products nor in intracellular substances. Consequently, it is probably localized in outer components of the cell. On the basis of their observations, Nagai et al. (1996) postulated that, if a toxic substance caused the death of pearl oysters, it might be contained in the cell surface of $H$. circularisquama. This was evjdently verified in the present study. However, sonicated cells which contain the whole, but physically broken-down, products of the outer components showed low inhibitory effect on the clearance rate (see Table 2). It is likely that the toxin localized on the cell surface is easily inactivated once it is released from the cell surface.

The filtration process of bivalves is sometimes influenced by chemical materials on food particles at the pre-ingestion stage. The reduction of clearance rate in bivalve mollusks exposed to Aureococcus anophagef- ferense is brought about by digestion of the extracellular coat, which releases a dopamine-mimetic compound that brings about the arrest of the lateral cilia in certain species (Gainey \& Shumway 1991). Dopamine is known to inhibit filtration rates of bivalves (Jones \& Richards 1993) due to reduction of ciliary activity (see Aiello 1990) and the siphon opening (Fong et al. 1993. Jones \& Richards 1993). In addition, allelochemical effects of dissolved ectocrine on clearance rates of bivalves were also demonstrated for some microalgae (Ward \& Targett 1989, Ward et al. 1992). Recent studies reveal that chemical interactions between microalgae and filtering activity of bivalves are generally found (Ward et al. 1992).

The toxic effect of Heterocapsa circularisquama on blue mussels decreased after gentle treatment of the alga with trypsin. Trypsin hydrolyzes various types of protein and polypeptides; therefore, it is probable that a protein (or polypeptide) complex on the surface of $H$. circularisquama is toxic. Toxic effects were decreased by SDS treatment in this study. SDS is known to break down protein to polypeptides. However, other surfaceactive chemicals which have lower protein degradation activities (sodium deoxycholate) were not as effective as SDS.

Phytoplankton have various types of species-specific substances, such as glycoprotein and carbohydrates, on the cell surface (Yokote \& Honjo 1985. Yokote et al. 1985, Costas \& Rodas 1994, Waite et al. 1995). These substances are known to be important in cell recognition and reception of chemical information (Hughes 1975). A polysaccharide-protein complex released extracellularly by Heterosigma akashiwo i= H. carterae, Taylor 1992) acts as an allelopathic substance which plays an important role in phytoplankton succession during $H$. akashiwo blooms (Honjo 1993). In addition, enzymes such as alkaline phosphatase and L-aminooxydase (Palenik \& Morel 1990) are present on the phytoplankton cell surface. In the present study, certain protein compounds on the surface of $H$. circularisquama cells inhibited the filtering behavior of $M$. galloprovincialis. Further investigations are necessary to clarify the interaction between phytoplankton and filter-feeding bivalves.

In addition, there is a possible concern that human consumption of bivalves which have accumulated Heterocapsa circularisquama may lead to illness; however no human poisoning or shellfish poisoning has ever been reported during a bloom of $H$. circularisquama. Direct HPLC analysis has detected neither PSP toxins nor DSP toxins in the cells of $H$. circularisquama ( $\mathrm{S}$. Sakamoto \& $\mathrm{T}$. Suzuki pers. comm.). On the basis of previous studies, it is concluded that $H$. circularisquama blooms do not pose a risk to human health. 


\section{Ecological importance}

Mytilus galloprovincialis significantly reduced its clearance rate even at low concentrations of Heterocapsa circularisquama (50 cells $\mathrm{ml}^{-1}$ ). Field observers noted that during a $H$. circularisquama bloom at densities from 50 to 200 cells $\mathrm{ml}^{-1}$, pearl oysters showed obvious refusal behaviors such as clapping, valve closure and contraction of the mantle (Matsuyama et al. 1996). This may contribute to the development of red tides of this dinoflagellate since dense populations of suspension-feeding bivalves might otherwise control apparent phytoplankton growth by feeding on the ambient edible phytoplankton at high rates (Jørgensen 1990). Significant reduction of the phytoplankton standing crop by suspension-feeding bivalves has been reported in the Potomac River (Cohen et al. 1984). In fact, $H$. circularisquama red tides frequently appear in embayments in Japan where intensive commercial bivalve culture of pearl oysters, oysters, and short-neck clams is being conducted. Thus, the inhibitory effect of $H$. circularisquama on bivalve clearance rates might, itself, be of great advantage for the development of red tides.

In summary, we determined the clearance rates of blue mussel Mytilus galloprovincialis exposed to variously treated cells of Heterocapsa circularisquama and showed that significant toxic effects, as manifested in the filtration processes of this bivalve, are regulated by a protein-like substance present on the surface of $H$. circularisquama cells.

Acknowledgements. We thank the members of the Fisheries Research Institute of Mie for providing us with seawater samples for the isolation of the $H$. circularisquama and Dr S. Itakura of Nansei National Fisheries Research Institute for kindly providing us with the culture of 1 . galbana used in the experiments. We are grateful to Dr H. Iwasaki of Mie University and Dr T Suzuki (Tohoku National Fisheries Research Institute) for the HPLC analysis on the PSP and DSP toxins of the samples. Thanks are also due to Dr T Ikeda of Hokkaido University for comments on the experiments. We extend our appreciation to Dr M. Maeda for critically reading the manuscript. This work was supported in part by a grant from the Nansei National Fisheries Research Instıtute, Fisheries Agency of Japan (Contribution no. B610).

\section{LITERATURE CITED}

Aiello E (1990) Nervous control of gill ciliary activity in Mytilus edulis. In: Stefano GB (ed) Neurobiology of Mytilus edulis. Manchester University Press, Manchester, p $189-208$

Ali RM (1970) The influence of suspension density and temperature on the filtration rate of Hiatella arctica. Mar Biol 6:291-302

Anderson DM (1994) Red tide. Sci Am 271:52-58

Brand LE, Guillard RRL, Murphy LS (1980) A method for the rapid and precise determination of acclimated phytoplankton reproduction rates. J Plankton Res 3:193-201

Chen LCM, Edelstein T, McLachlan J (1969) Bonnemaisonia hamifera Hariot in nature and in culture. J Phycol 5: $211-220$

Cohen RRH, Dresler PV, Phillips EJP, Cory RL (1984) The effect of the Asiatic clam, Corbicula fluminea, on phytoplankton of the Potomac River, Maryland. Limnol Oceanogr 29:170-180

Costas E, Rodas VL (1994) Identification of marine dinoflagellates using fluorescent lectuns. J Phycol 30:987-990

Coughlan J (1969) The estimation of filtering rate from the clearance of suspensions. Mar Biol 2:356-358

Fong PP, Noordhuis R, Ram JL (1993) Dopamine reduces intensity of serotonin-induced spawning in zebra mussel Dreissena polymorpha (Pallas). J Exp Zool 266:79-83

Gainey LF Jr, Shumway SE (1988) A compendium of the responses of bivalve molluscs to toxic dinoflagellates. J Shellfish Res 7:623-628

Gainey LF Jr, Shumway SE (1991) The physiological effect of Aureococcus anophagefferens ('brown tide') on the lateral cilia of bivalve mollusks. Biol Bull 181:298-306

Hallegraeff GM (1993) A review of harmful algal blooms and their apparent global increase. Phycologia 32:79-99

Heinig CS, Campbell DE (1992) The environmental context of a Gyrodinium aureolum bloom and shellfish kill in Maquoit Bay; Maine, September 1988. J Shellfish Res 11. $111-122$

Honjo T (1993) Overview on bloom dynamics and phsiological ecology of Heterosigma akashiwo. In: Smayda TJ, Shimuzu Y (eds) Toxic phytoplankton bloom in the sea Elsevier, Amsterdam, p 33-42

Honjo T (1994) The biology and prediction of representative red tides associated with fish kills in Japan. Rev Fish Sci 2: $225-253$

Horiguchi $T$ (1995) Heterocapsa circularisquama sp. nov. (Peridiniales, Dinophyceae): a new marine dinoflagellate causing mass mortality of bivalves in Japan. Phycol Res 43:129-136

Hughes RC (1975) The complex carbohydrates of mammalian cell surfaces and their biological roles. Essays Biochem 11: $1-36$

Itoh K, Imai I (1987) Rafido-So. In: The Japan Fisheries Resource Conservation Association (ed) A guide for studies of red tide organisms. Shuwa, Tokyo, p 122-130 (in Japanese)

Jones HG, Richards OG (1993) The effects of acetylcholine, dopamine and 5-hydroxytryptamine on water pumping rate and pressure in the mussel Mytilus edulis L. J Exp Mar Biol Ecol 170:227-240

Jørgensen CB (1990) Bivalve filter feedıng: Hydrodynamics, bioenergetics, physiology and eology. Olsen \& Olsen. Fredensborg, Denmark, p 50-66

Lesser MP, Shumway SE (1993) Effects of toxic dinoflagellates on clearance rates and survival in juvenile bivalve molluscs. J Shellfish Res 12:377-381

Mahoney JB, Olsen P, Cohn M (1990) Blooms of a dinoflagellate Gyrodinium cf aureolum in New Jersey coastal waters and their occurrence and effects worldwide. J Coast Res 6:121-135

Matsuyama $Y$, Nagai $K$, Mizuguchi $T$, Fujiwara M, Ishimura $M$, Yamaguchi $M$, Uchida T, Honjo T (1995) Ecological features and mass mortality of pearl oysters during the red tide of Heterocapsa sp. in Ago Bay in 1992. Nippon Suisan Gakkaishi 61:35-41 (in Japanese)

Matsuyama $Y$, Uchida T, Nagai $K$, Ishimura M, Nishimura A, Yamaguchi M, Honjo T (1996) Biological and environmen- 
tal aspects of noxious dinoflagellate red tides by Heterocapsa circularisquama in the west Japan. In: Yasumoto $T$, Oshima $Y$, Fukuyo $Y$ (eds) Harmful and toxic algal blooms. Intergovernmental Oceanographic Commission of UNESCO, Paris, p 247-250

Nagai K, Matsuyama $Y$, Uchida T, Yamaguchi M, Ishimura M. Nishimura A, Akamatsu S, Honjo T (1996) Toxicity and $\mathrm{LD}_{50}$ levels of the red tide dinoflagellate Heterocapsa circularisquama on juvenile pearl oysters. Aquaculture 144 $149-154$

Nielsen MV, Stromgren T (1991) Shell growth response of mussels (Mytilus edulis) exposed to toxic microalgae. Mar Biol 108:263-267

Omor M, Ikeda T (1984) Methods in marine zooplankton ecology. John Wiley \& Sons, New York

Palenik B, Morel FMM (1990) Comparison of cell surface L. amino acid oxidases from several marine phytoplankton. Mar Ecol Prog Ser 59:195-201

Schulte EH (1975) Influence of algal concentration and temperature on the filtration rate of Mytilus edulis. Mar Biol $30: 331-341$

Shumway SE (1990) A review of the effects of algal blooms on shelifish and aquacuiture. j Worid Aquaculture Sor 21 $65-104$

Shumway SE, Cucci TL, Newell RC, Yentsch CM (1985) Particle selection, ingestion, and absorption in filter-feeding bivalves. J Exp Mar Biol Ecol 91:77-92

Taylor FJR (1992) The taxonomy of harmful marine phytoplankton. G Bot Ital 126:209-219

Uchida T, Yamaguchi M, Matsuyama Y, Honjo I (1995) The red-tide dinoflagellate Heterocapsa sp. kills Gyrodinium instriatum by cell contact. Mar Ecol Prog Ser 118:301-303

Waite AM, Olsen RJ, Dam HG, Passow U (1995) Sugar-con-

This article was submitted to the editor taining compounds on the cell surfaces of marne diatoms measured using concanavalin $A$ and flow cytometry. J Phycol 31:925-933

Ward JE, Cassel HK, MacDonald BA (1992) Chemoreception in the sea scallop Placopecten magellanicus (Gmelin). I. Stimulatory effects of phytoplankton metabolites on clear ance and ingestion rates. J Exp Mar Biol Ecol 163:235-250

Ward JE, Targett NM (1989) Influence of marine microalgal metabolites on the feeding behavior of the blue mussel Mytilus edulis. Mar Biol 101:313-321

Widdows J, Moore MN, Lowe DM, Salkeld PN (1979) Some effects of a dinoflagellate bloom (Gyrodinium aureolum) on the mussel Mytulus edulis. J Mar Biol Ass UK 59: $522-524$

Wikfors GH, Smolowitz RM (1995) Experimental and histological studies of four life-history stages of the eastern oyster, Crassostrea virginica, exposed to a cultured strain of the dinoflagellate Prorocentrum minımum. Biol Bull 188 $313-328$

Winter JE (1978) A review on the knowledge of suspensionfeeding in lamellibranchiate bivalves, with special reference to artificial aquaculture systems. Aquaculture 13: $1-33$

Yamamoto C, Tanaka Y (1990) Two species of harmful red tide plankton increased in Fukuoka Bay. Bull Fukuoka Fish Exp Stn 16:43-44 (in Japanese)

Yokote M, Honjo T (1985) Morphological and histochemical demonstration of a glycocalyx on the cell surface of Chattonella antiqua, a 'naked flagellate' Experientia 41: $1143-1145$

Yokote M, Honjo T, Asakawa M (1985) Histochemical demonstration of a glycocalyx on the cell surface of Heterosigma akashiwo. Mar Biol 88:295-299

Manuscript first received: September 10, 1996 Revised version accepted: November 11, 1996 